\title{
SISTEM REMUNERASI BERBASIS KINERJA PEGAWAI NEGERI SIPIL DI KABUPATEN SORONG
}

\author{
Arie Purnomo $^{*}$, Masni Banggu ${ }^{2}$ \\ Program Studi Ilmu Pmerintahan Universitas Muhammadiyah Sorong \\ Program Studi Ilmu Pmerintahan Universitas Muhammadiyah Sorong \\ Korespondensi* ari.170182@gmail.com
}

\begin{abstract}
This study aims to determine the performance-based remuneration system for civil servants in Sorong Regency. The research was conducted at the Regional Civil Service Agency of Sorong City. The research method used is a qualitative descriptive approach, namely a research approach that reveals certain social situations by describing reality correctly. Data collection techniques are carried out through observation, interviews, documentation, then the data is analyzed appropriately and correctly to make it easier for other researchers to understand it. The results of this study indicate that the performance-based remuneration system of Civil Servants implemented in the Office of the Personnel, Education and Training Agency of Sorong Regency has a very strong influence on employee performance so that employees can work better, more actively because most of the civil servants have not worked properly. effective and efficient so it is hoped that with the remuneration system from the local government, employees can work well and be disciplined.
\end{abstract}

Keywords: Remuneration System, Employee Performance

\begin{abstract}
ABSTRAK
Penelitian ini bertujuan untuk mengetahui sistem remunerasi berbasis kinerja pegawai negeri sipil di Kabupaten Sorong. Penelitian dilaksanakan pada Badan Kepegawaian Daerah Kota Sorong. Metode penelitian yang digunakan adalah pendekatan deskriptif kualitatif yaitu pendekatan penelitian yang mengungkapkan situasi sosial tertentu dengan mendeskripsikan kenyataan secara benar dengn teknik pengumpulan data dilakukan melalui observasi, wawancara, dokumentasi, kemudian data dianalisis secara tepat dan benar untuk memudahkan para peneliti lain memahaminya. Hasil penelitian ini menunjukan bahwa sistem remunerasi berbasis kinerja Pegawai Negeri Sipil yang diterapkan di kantor Badan Kepegawian, Pendidikan dan pelatihan Kabupaten Sorong, sangat berpengaruh pada kinerja Pegawai sehingga Pegawai dapat bekerja lebih baik, lebih giat karena sebagian besar pegawai negeri sipil selama ini tidak bekerja secara efektif dan efisien sehingga diharapkan dengan adanya sistem remunerasi dari pemerintah daerah maka pegawai dapat bekerja secara baik dan disiplin.
\end{abstract}

Kata Kunci: Sistem Remunerasi, Kinerja Pegawai

PENDAHULUAN

Remunerasi merupakan pemberian hadiah penghargaan atas jasa dan sebagainya.
Setiap pegawai negeri sipil berhak memperoleh gaji yang adil dan layak sesuai dengan beban pekerjaandantanggungjawabanya.Remunerasi merupakan bagian yang tidak terpisahkan dari 


\section{Noken Vol. 6 (No.1) Halaman: 49-62 2020}

Kebijakan Reformasi Birokrasi. Hal ini tidak terlepas dari kesadaran sekaligus komitmen pemerintah untuk mewujudkan "clean and good governance" pemerintahan yang bersih dan baik (Listiawati, D. Y., Suaib, M. R., \& Purnomo, A. 2018).

\section{Pada kenyataan pelaksanaannya,} perubahan dan pembaharuan yang dilaksanakan dalam rangka mewujudkan tata pemerintahan yang bersih dan berwibawa tersebut tidak mungkin akan dapat dilaksanakan dengan baik atau efektif tanpa kesejahteraan yang layak dari Pegawai Negeri Sipil yang menjadi pengggerak roda pemerintahan. Reformasi Birokrasi harus dilakukan untuk menghapus, memperbaiki citra Pemerintahan yang selama ini telah terpuruk di mata masyarakat, beberapa indikator yang dapat dilihat selama ini diantaranya; a) Buruknya kualitas pelayanan publik atau lambat, tidak ada kepastian aturan/hukum, berbelit-belit, minta dilayani dan sebagainya; b) Sarat dengan perilaku KKN (Korupsi, Kolusi, Nepotisme); c) Rendahnya kualitas disiplin dan etos kerja pegawai negeri; d) Kualitasmanajemen pemerintahan yang tidak produktif, tidak efektif dan tidak efisien; e) Kualitas pelayanan publik yang tidak akuntabel dan tidak transparan.

Pemberian remunerasi hanya berdasarkan untuk meningkatkan tingkat kesejahteraan saja, ternyata juga tidak serta merta dapat mengeleminir permasalahan-permasalahan yang ada, sehingga diperlukan manajemen strategi dalam pemberian remunerasi, salah satunya dengan cara "remunerasi berbasis kinerja". Remunerasi bermakna sangat strategis terhadap suksesnya Reformasi Birokrasi, mengingat dampak paling signifikan terhadap kinerja di kantor akan sangat ditentukan oleh perubahan kultur PNS di dalam melaksanakan tugas pokoknya. Sedangkan keberhasilan merubah kultur tersebut sangat ditentukan oleh tingkat kesejahteraan anggotanya.

Prinsip dasar kebijakan Remunerasi adalah adil dan proporsional. Artinya kalau kebijakan menerapkan pola sama rata, maka dengan kebijakan Remunerasi, besar penghasilanyang diterima oleh seorang pejabat akan sangat ditentukan oleh bobot dan harga jabatan yang disandangnya serta kinerja yang dihasilkan. (Muhammad Surya, 2004)

Pertama harus disadari bahwa sejalan dengan perkembangan demokrasi dan kesadaran hukum masyarakat yang semakin matang, maka tuntutan masyarakat untuk dilayani, dilindungi, dan disejahterakan oleh Pemerintah sebagai representasi negara juga semakin meningkat. Termasuk tekanan dan tuntutannya terhadap perubahan kinerja PNS. Oleh sebab itu 


\section{Noken Vol. 6 (No.1) Halaman: 49-62 2020}

pemerintah harus segera menyesuaikan diri dengan tuntutan perubahan tersebut. karena jika tidak responsif dan tidak adaptif dengan perubahan tersebut pemerintah akan kehilangan legitimasinya dimata masyarakat.

Sistem remunerasi mencakup semua bentuk imbalan baik secara langsung, maupun tidak langsung, dan yang bersifat rutin maupun tidak rutin. Remunerasi pun tidak dapat disangkal, karena merupakan harapan utama setiap pegawai terhadap kantornya. Remunerasi juga menjadi salah satu cara dominan bagi kantor dalam mempertahankan para pegawainya. Dengan remunerasi yang baik, pegawai akan merasa puas dan nyaman sehingga mereka akan bekerja dengan produktif yang pada akhirnya akan membantu kantor mencapai tujuannya. (Purnomo, A. 2018).

Pada tataran pelaksanaanya, perubahan dan pembaharuan yang dilaksanakan dalam rangka mewujudkan tata pemerintahan yang bersih dan berwibawa tersebut tidak mungkin akan dapat dilaksanakan dengan baik atau efektif tanpa kesejahteraan yang layak dari pegawai negeri sipil.

Prinsip dasar system remunerasi adalah adil dan proposional artinya kalau system remunerasi menerapkan pola sama rata. Maka dengan system remunerasi, besar penghasilan yang di terima oleh seorang pegawai negeri sipil sangat di tentukan oleh bobot dan harga jabatan yang di sandangkanya.Sumber daya pegawai negeri sipil adalah meningkatkan kinerja operasional pegawai dalam melaksanakan tugastugas pemerintah. Sumber daya pegawai negeri sipil merupakan asset utama. Dalam organisasi yang menjadi pelaku dan perencana aktif dari setiap aktivitas dalam organisasi. Sulistiyani, S., Amiruddin, A., \& Purnomo, A. (2019).

Kesejahteraan pegawai atau karyawan merupakan salah faktor penting dalam pencapaian tujuan suatu kantor, karena dengan adanya pegawai atau karyawan semua pekerjaan kantor dapat terselesaikan.

\section{METODE PENELITIAN}

Penelitian ini termasuk dalam jenis penelitian deskriptif kualitatif. Penilitian deskriptif kualitatif adalah suatu pendekatan penelitian yang mengungkapkan situasi sosial tertentu dengan mendeskripsikan kenyataan secara benar, dibentuk oleh kata-kata berdasarkan teknik pengumpulan dan analisis data yang relevan yang diperoleh dari situasi yang alamiah (Sugiyono. 2009:57). Penggunaan metode ini bertujuan untuk mendapatkan gambaran secara jelas, lengkap, rinci, dan mendalam terkait 


\section{Noken Vol. 6 (No.1) Halaman: 49-62 2020}

dengan fenomena yang diteliti. Selain itu untuk mendapatkan data dilapangan menggunakan survei, yaitu suatu teknik pengumpulan data dan informasi yang dilakukan dengan cara pengamatan langsung ke lokasi penelitian dan pencatatan secara sistematis terhadap sistem remunerasi berbasis kinerja pegawai negeri sipil di kantor Badan Kepegawaian Daerah Kabupaten Sorong. Untuk mendapatkan data secara terperinsi penulis juga menggunakan teknik wawancara dan mendokumentasikan semua data penelitian agar peneliti mudah mengingat dan mengintepretasikan data secara baik, tepat dan benar bagi para pembaca.

\section{HASIL DAN PEMBAHASAN}

\section{Sistem Remunerasi Berbasis Kinerja Pegawai Negeri Sipil di Kabupaten Sorong.}

Telah dijelaskan sebelumya tentang arti dan pentingnya Sistem Remunirasi Berbasis Kinerja Pegawai Negeri Sipil di Kabupaten Sorong, maka dalam pembahasan ini penulisan secara rinci menguraikan atau membahas tentang sistem kinerja pegawai negeri sipil di kabupaten Sorong dalam melaksanakan kinerjanya. Selanjutanya mengingat faktor-faktor apa saja yang dapat menghambat sistem remunerasi berbasis kinerja pegawai negeri sipil, dan upayaupaya apa saja yang akan dilakukan oleh pemerintah daerah, dengan demikian maka pada awal penulisan ini akan dijelaskan melalui beberapa tahapan yang perlu diketahui antara lain.

\section{Remunerasi}

Remunerasi adalah pemberian gaji atau pendapatan tambahan kepada seorang pegawai sebagai apresiasi atas pekerjaan atau kontribusi dalam perusahaan yang sifatnya rutin dimana ia bekerja. Atau bisa juga disebut sebagai sesuatu yang diterima oleh seorang pegawai atau karyawan dari tempat ia bekerja. (Purnomo, A. (2018).

Biasanya hal ini diberikan koleh perusahaan kepada pegawai atau karyawan atas prestasi kerja yang sudah dilakukan. perusahaan yang menerapkan kebijakan dengan pemberian remunerasi ini sangat menguntungkan bagi karyawannya dan juga perusahaan. Terdapat dua unsur utama remunerasi yaitu kompensasi dan bonus (komisi). Kompensasi berhubungan dengan keseluruhan yang diterima tenaga kerja baik dalam berupa fisik maupun non fisik. Dalam beberapa hal, kompensasi seringkali tidak dikenai pajak pendapatan.

Sedangkan komisi atau bonus merupakan bentuk imbalan yang diberikan kepada pegawai dengan perhitungan presentase hasil penjualan. Bonus juga diberikan berdasarkan kemampuan 


\section{Noken Vol. 6 (No.1) Halaman: 49-62 2020}

pegawai untuk mencapai target. Dalam hal ini sebagaimana wawancara penulis dengan informan Ibu Fanny Minarni S.H.M.H. beliau mengatakan bahwa;

"Dengan adanya Sistem remunerasi berbasis kinerja Pegawai Negeri Sipil yang diterapkan di kantor Badan Kepegawian, Pendidikan dan pelatihan daerah sangat berpengaruh pada kinerja Pegawai sehingga Pegawai dapat bekerja lebih baik, lebih giat karena sebagian besar pegawai negeri sipil selama ini tidak bekerja secara efektif dan efisien diharapkan dengan adanya sistem remunerasi dari pemerintah daerah maka pegawai dapat bekerja secara baik dan disiplin" (Wawancara Rabu 3 Oktober 2020)

Dengan adanya sistem remunerasi atau tambahan penghasilan dari pemerintah daerah maka sebagian besar pegawai negeri sipil di kabupaten sorong akan bekerja lebih rajin, giat dan tekun, dan akan bekerja sesuai dengan kinerjanya masing-masing.

\section{Tujuan Memberikan Remunerasi}

Tentunya kantor atau perusahaan yang memberikan remunerasi memiliki beberapa tujuan yang sifatnya untuk meningkatkan kualitas kantor atau perusahaan dan juga karyawannya. Namun untuk lebih lengkapnya, berikut adalah beberapa tujuannya;

\section{Menjadikan SDM yang Berkualitas;} Dengan adanya remunerasi diharapkan terciptanya sumber daya manusia (SDM) yang berkualitas di sebuah perusahaan atau organisasi. Adanya pemberian pendapatan tambahan juga akan mendorong tenaga kerja untuk meningkatkan kualitas kerjanya. Darihasil wawancara penulis dengan informan Ibu Sanderina Abigael Su, A.md beliau mengatakan bahwa :

"Dalam setiap lapangan pekerjaan semakin dibutuhkan tersedianya sumber daya manusia yang handal baik dalam hal kuantitas maupun kualitas. Oleh karena itu, perlu adanya penilaian kompetensi sumber daya manusia, baik dalam rangka rekrutmen maupun pembinaan bagi sumber daya manusia yang telah tersedia. Tujuan pelaksanaan penilaian kompetensi adalah untuk mendapatkan data dan profil sumber daya manusia yang diperlukan, guna menjadi dasar penilaian atau seleksi lebih lanjut, serta pengembangan kompetensi selanjutnya. Minimal, bagi orang yang dinilai, ia dapat merencanakan pengembangan dirinya sendiri atau merencanakan karirnya. Sementara itu, bagi organisasi, penilaian kompetensi ini perlu dalam rangka penyusunan database profil kompetensi sumber daya manusianya, sebagai dasar penerapan manajemen sumber daya manusia yang transparan, kompetitif, dan berbasis merit, serta menjadi dasar bagi upaya pengembangan kompetensi kepemimpinan untuk perubahan budaya kerja dan budaya organisasi." (Wawancara 3 Oktober 2020) 


\section{Noken Vol. 6 (No.1) Halaman: 49-62 2020}

Dengan adanya remunerasi maka terciptanya pegawai yang handal, berkualitas, dengan adanya SDM yang unggul perlu penilaian kompetensi sumber daya manusia untuk mengembangkan dirinya sendiri atau merencanakan karirnya sehingga sebagai dasar penerapan manajemen sumber daya manusia yang transparan, kompetitif, dan berbasis merisistem, serta menjadi dasar bagi upaya pengembangan kompetensi kepemimpinan untuk perubahan budaya kerja dan budaya organisasi. (Sulistiyani, S., Amiruddin, A., \& Purnomo, A. (2019). Untuk menggali tingkat kompetensi dari orang yang dinilai, yang merupakan kombinasi dari kemampuan kognitif, afektif dan psikomotorik serta kristalisasi pengalamannya dalam menghadapi realitas pekerjaannya.

\section{Memotivasi Karyawan untuk} Mengembangkan Diri; Remunerasi akan memicu adanya motivasi dalam diri pekerja untuk bekerja lebih baik dan juga bisa mengenbangkan potensi dirinya. Hal ini juga bisa mencipatakan pesaingan yang positif antar karyawandi perusahaan. Perusahaan akan menilai mana karyawan yang memiliki semangat kerja tinggi serta memiliki keinerja yang baik atau tidak. Tentunya hal ini sangat peting bagi perusahaan agar dapat memotivasi karyawannya untuk terus mengembangkan dirinya. (Syama, M., Amiruddin, A., \& Purnomo, A. (2019).

Darihasil wawancara penulis dengan informan Ibu Fanny Minarni S.H.M.H. beliau mengatakan bahwa;

"Mengapresiasi pekerjaan karyawan atas pencapaian pekerjaannya bisa menjadi boomerang penyemangat bagi kinerja karyawan. Bentuk apresiasi ini bisa berupa bonus tahunan, insentif bulanan, maupun kenaikan jabatan jika memang kinerjannya sangat bagus. Satu hal yang perlu diperhatikan bahwa pemberian apresiasi ini jangan samapai menibulkan rasa iri pada karyawan yang lain. Pemberian apresiasi ini haruslah berdasarkan asas keadilan. Kantor harus melakukan pengamatan dan penilaian yang adil pada semua karyawan. Pemberian apresiasi kepada karyawan harus benar-benar disesuaikan kinerja masing-masing karyawan. Dengan begitu, setiap karywan secara otomatis dan termotivasi, akan memperbaiki kinerjanya sendiri." (Wawancara 3 Oktober 2020)

Mensejahterakan Karyawan; Tentu dengan adanya remunerasi akan sangat membantu kesejateraan karyawan disuatu kantor. Karyawan yang biasanya hanya memperoleh gaji pokok saja kini mendapatkan tambahan. Hal ini akan membuat karyawan lebih semangat dalam bekerja, sebagaimana dikatakan oleh informan 
Bapak Yahya Syufan, S.sos beliau mengatakan bahwa;

"Setiap tugas-tugas yang dikerjakan oleh seorang ASN dapat dimasukan dibuku jurnal harian masing-masing. Sehingga setiap tugas-tugas yang dikerjakan Setiap ASN ditunjuk untuk melakukan kinerjanya dengan baik, melayani pegawai yang ada dilingkungan pemerintah Kabupaten Sorong sesuai dengan kebutuhannya, Karena berdasarkan kegiatan yang dikerjakan berdampak positif. Jadi setiap pegawai yang mendapatkan remunerasi atau tambahan penghasilan diharapkan dapat bekerja sesuai dengan kinerjanya masing-masing." (Wawancara 3 Oktober 2020).

Dengan adanya remunerasi itu juga akan memotivasi setiap karyawan atau pegawai disuatu kantor maka pegawai dapat bekerja dengan baik dan tekun dalam pekerjaannya karena dengan gaji pokok saja tidak cukup tetepi dengan tujuan pemerintah untuk memberikan remunerasi atau tambahan penghasilan maka setiap pegawai dapat bekerja sesuai dengan kinerjanya.

\section{Hal-Hal Yang Perlu Dipertimbangkan Dalam Pemberian Remunerasi}

\section{Memberikan Gaji Sesuai Kinerja;}

Pegawai atau karyawan yang bertanggungjawab untuk pekerjaan yang berat dan berisiko sudah wajar untuk mendapatkan remunerasi atau tambahan penghasilan. Selain itu juga pegawai atau karyawan yang mengerjakan tugas dengan cepat dan tepat serta bisa berkolaborasi dalam memgenbangkan suatu kantor atau perusahaan juga patut di berikan pendapatan tambahan.

Penghargaan dalam bentuk gaji atau remunerasi yang diberikan kantor atau perusahaan kepada pegawai atau karyawannya merupakan cara suatu kantor atau perusahaan menjaga karyawannya untuk memotivasi dan membentuk loyalitas kerja yang lebih baik. Pada kebanyakan pegawai atau karyawan jika tidak ada penghargaan yang diberikan dari kantor atau perusahaan tersebut, maka besar kemungkinan pegawai atau karyawan tersebut akan bekerja tidak sesuai dengan kinerjanya, karena ia menganggap prestasi kerjanya tidak dilihat oleh kantor atau perusahaan dan tidak dihargai. Sebagaimana wawancara penulis dengan informan Ibu Sanderina Abigael Su, A.md beliau mengatakan bahwa;

"Pada dasarnya, gaji yang diterima oleh karyawan harus sesuai dengan beban kerja yang diberikan oleh kantor atau perusahan. Semakin menantang atu rumit pekerjaan tersebut, maka dibutuhkan seorang karyawan yang memiliki latar belakang pendidikan atau pengalaman yang sesuai. Oleh karena itu, sudah sepatutnya karyawan mendapatkan gaji atau upah sesuai dengan kinerja atau tuntutan pekerjaan. “" (Wawancara 3 Oktober 2020). 


\section{Noken Vol. 6 (No.1) Halaman: 49-62 2020}

Dengan memberikan gaji sesuai kinerja maka gaji yang diterima oleh pegawai atau karyawan tersebut harus sesuai dengan beban kerjanya, agar setiap pekerjaan yang dikerjakan oleh sorang pegawai atau karyawan dapat terselesaikan dengan baik dan dapat memajukan suatu kantor atau perusahan tersebut.

Memberikan Bonus Khusus Pegawai atau Karyawan Berprestasi; Pegawai atau karyawan yang berprestasi sudah sepatutnya diberikan penghargaan. Pemberian remunerasi ini akan membangkitkan semangat kerja serta loyalitas dalam diri pegawai atau karyawan itu sendiri. Sehingga ia akan semakin semangat dalam mengerjakan pekerjaan dan merasa dihargai. Dari hasil wawancara penulis dengan informan Bapak Yahya Syufan, S.sos beliau mengatakan bahwa;

"Biasanya kantor atau perusahan memberikan bonus, khusus untuk mengapresiasi prestasi yang telah di capai karyawan, dimana pemberianya dilakukan secara tahunan. Misalnya, ada karyawan yang berhasil mencapai target selama beberapa bulan berturut-turut, maka tak ada salahnya kantor memberikan bonus prestasi sebagai bentuk apresiasi." (Wawancara 3 Oktober 2020).

Dari hasil wawancara diatas penulis simpulkan bahwa kantor atau perusahan memberikan bonus apabila seorang pegawai atau karyawan berhasil mencapai target kinerjanya secara berturut-turut pekerjaanya.

\section{Menaikkan Gaji Karyawan;}

Memberikan kenaikan gaji bagi karyawan merupakan salah satu cara untuk menjaga kinerja dan loyalitas pegawai. Pemberian peningkatan gaji kepada pegawai atau karyawan akan memberikan dampak kepada kinerja pegawai atau karyawan itu sendiri. Besar kecilnya gaji bisa menjadi salah satu tolak ukur kualitas karyawan di sebuah kantor atau perusahaan. Hal ini sebagaimana wawancara penulis dengan informan Ibu Sanderina Abigael Su, A.md beliau mengatakan bahwa;

"Sistem remunerasi dan kinerja itu berbeda dalam arti bahwa, sistem remunerasi atau tambahan penghasilan pegawai itu adalah soal kehadiran masing-masing pegawai, atau soal kedisiplinan, itu dihitung dalam setiap kinerja pegawai. Sedangkan kinerja adalah pekerjaan yang sudah ditentukan atau diberikan untuk setiap pegawai agar bisa dapat bekerja sesuai dengan kinerjanya masing-masing. Karena penilain tingkat kehadiran itu $70 \%$ sedangkan kinerja 30\% tetapi Menurut Ibu Sanderina Abigael Su, A.md kinerja baru berjalan tiga bulan tetapi seiring dengan berjalannya waktu akan berjalan dengan seimbang menjadi tingkat kehadiran 50\% dan kinerjanya 50\% Jadi setiap pegawai yang ingin mendapatkan remunerasi atau tambahan penghasilan harus bekerja secara efektif dan efisien." (Wawancara 3 Oktober 2020). 


\section{Noken Vol. 6 (No.1) Halaman: 49-62 2020}

Setiap pegawai yang mendapatkan remunerasi atau tambahan penghasilan harus bisa bertanggunjawab dalam pekerjaannya sesuai dengan kinerjanya. Bagi pegawai yang sudah bekerja aktif sesuai dengan kinejanya sudah patut mendapatkan remunierasi atau tambahan penghasilan sesuai dengan apa yang pegawi itu bekerja atau sesuai kinerja dari setiap pegawai tersebut. setiap pegawai yang sudah bekerja sesuai dengan kinerjanya dan tidak pernah loyal dalam pekerjaannya berhak mendapatkan peningkatan gaji atau bonus tambahan gaji atau tambahan penghasilan.

\section{Faktor- faktor yang menghambat pelaksanaan sistem Remunerasi berbasis kinerja Pegawai Negeri Sipil di Kabupaten sorong.}

\section{Faktor Kinerja Seorang Pegawai}

Jika seorang pegawai tidak melaksanakan kinerjanya secara baik dan tekun dalam kinerjanya maka pegawai tersebut tidak berhak menerima remunerasi atau tambahan penghasilan, karena kinerja pegawai merupakan tingkat pencapaian atau hasil kerja seseorang dari sasaran yang harus dicapai atau tugas yang harus dilaksanakan sesuai dengan tanggung jawab masing-masing pegawai dalam kurun waktu tertentu. Sebagaimana wawancara penulis dengan informan Ibu Fanny Minarni S.H.M.H. beliau mengatakan bahwa;
"Faktor yang menghambat pelaksanaan sistem Remunerasi, yaitu kembali ke pribadi para aparatur sipilnya itu masingmasing, apakah para aparatur sipil tersebut dapat menaati aturan atau tidak? Misalnya setiap hari datang tepat waktu dan setiap hari mengisi Jurnal harian yang dituangkan dalam E kinerja. Ada juga pegawai yang tidak membuat atau mengisi jurnal mungkin karena mereka melihat bahwa komposisinya Cuma 30\%, jadi $70 \%$ kehadiran dan $30 \%$ Kinerja, jadi mereka menganggap bahwa itu Cuma kecil. Menurut Ibu Fanny Minarni S.H.M.H. Yang beliau ketahui bahwa dalam waktu yang berjalan komposisi tersebut akan berubah menjadi 50\% kehadiran dan $50 \%$ kinerja jadi sebenarnya jumlahnya akan seimbang dengan berjalannya waktu karena ini masih masa perkenalan artinya bahwa sistem remunerasi ini baru berjalan 3 bulan terhitung mulai dari bulan juli tahun 2020. “(Wawancara 3 Oktober 2020).

Dari hasil wawancara diatas penulis simpulkan bahwa faktor yang menghambat jalanya sistem remunerasi adalah kembali berpulang kepada masing-masing pegawai itu sendiri jika dia mau mendapatkan remunerasi atau tambahan penghasilan maka harus mengikuti semua syarat dan ketentuan yang sudah diterapkan oleh pemerintah daerah.

\section{Jurnal Harian}

Seorang pegawai harus mengisi jurnal harian sesuai dengan kinerjanya, atau sesuai dengan syarat dan ketentuan yang sudah di terapkan, karena jurnal harian adalah sesuatu 


\section{Noken Vol. 6 (No.1) Halaman: 49-62 2020}

syarat atau untuk mengetaui setiap kinerja seorang pegawai dalam mendaptkan remunerasi atau tambahn penghasilan.

Dari hasil wawancara penulis dengan informan Bapak Yahya Syufan, S.sos beliau mengatakan bahwa;

"Faktor yang dapat menghambat jalannya pelaksanaan sistem remunerasi adalah kembali berpulang kepada masing-masing ASN itu sendiri, ketika dia lihat bahwa remunerasi atau tambahan penghasilan itu penting berarti harus dia melakukan tugas-tugasnya sesuai dengan kinerjanya, karena kalau dia cuman mengharapkan gaji pokoknya saja tidak cukup sehingga dapat menyebabkan dia tidak bekerja secara aktif sesuai dengan kinerjanya. Dan juga harus mengisi jurnal harian karena kalu dia tidak mengisi jurnal harian berarti tidak bisa mengetahui kinerjanya. Jadi harus mengisi jurnal harian sesuai dengan kinerjanya." (Wawancara 3 Oktober 2020)

Setiap Pejabat wajib menilai jurnal harian bawahannya dengan nilai $0 / 1 / 2$. Nilai 0 berarti pegawai tidak melakukan pekerjaan tersebut. Nilai 1 berarti pegawai melaksanakan tugas tersebut dinilai hanya setengah pekerjaan. Dan nilai 2 berarti pegawai telah sesuai dalam melaksanakan tugasnya. Pengisian jurnal harian akan berpengaruh pada pemenuhan SKP Pegawai. Sasaran Kinerja Pegawai yang selanjutnya disingkat SKP adalah rencana kinerja dan target yang akan dicapai oleh seorang PNS yang harus dicapai setiap tahun. SKP pegawai nantinya akan dinilai oleh Atasan Langsung. Terkait dengan penilaian kinerja pegawai negeri sipil, penilaian tersebut diatur dalam Peraturan Pemerintah Republik Indonesia Nomor 30 Tahun 2019 tentang Penilaian Kinerja Pegawai Negeri Sipil. Dengan adanya sistem remunerasi atau tambahan penghasilan maka setiap pegawai diharapkan supaya wajib mengisi jurnal harian dan melakukan setiap pekerjaan-pekerjaan sesuai dengan kinerjanya masing-masing dan mendapat penilaian dari pada pimpinan dimkana dia bekerja.

\section{Waktu}

Salah satu yang menghambat pegawai dalam mendapatkan remunirasi yaitu masalah waktu, karena setiap pegawai ada juga yang datang tidak sesuai dengan waktu yang sudah di sepakti bersama, sehingga dapat menghambat jalanya kinerja seorang pegawai dalam mendapatkan remunerasi atau tambahan penghasilan, sebagaimana yang di katakana oleh informan Ibu Sanderina Abigael Su, A.md beliau menjelaskan bahwa;

"Faktor yang menghambat pelaksanaan atau berjalanya sistem remunirasi yaitu datang tidak pernah tepat waktu, sengaja lalai dalam pekerjaannya, malas untuk mengisi jurnal harian baik secara sengaja maupun tidak sengaja, jarang mengikuti setiap sosialisasi-sosialisasi, 
tidak bekerja secara aktif, dan semunya itu berpulang kepada aparatur sipil masing-masing." (Wawancara 3 Oktober 2020)

Pernyataan di atas menggambarkan bahwa faktor yang menghambat jalanyan sistem remunerasi adalah masalah waktu jika seorang pegawai tidak datang sesuai dengan waktu yang sudah di tentukan maka itu juga dapat menghambat kinerjanya seorang pegawai tersebut

\section{Upaya Apa Saja yang Dilakukan dalam Penerapan Sistem Remunerasi Berbasis Kinerja Pegawai}

\section{Sosialisasi}

Sosialisasi adalah proses penanaman atau transfer kebiasaan atau nilai dan aturan dari satu generasi ke generasi lainnya dalam sebuah kelompok atau masyarakat. Sosialisasi sebagai teori mengenai peranan Karena dalam proses sosialisasi diajarkan peran-peran yang harus dijalankan oleh individu.

Salah satunya upaya adalah dengan memberikan sosialisasi kepada setiap pegawai, makapegawai tersebut pada akhirnya dapat melakukan setiap pekerjaan-pekerjaan yang belum pernah diketauhinya dan pada akhirnya dapat melakukan setiap pekerjaan sesuai dengan kinerjanya. Lebih jelas wawancara penulis dengan informan Ibu Fanny Minarni S.H.M.H. beliau mengatakan bahwa;

"Upaya yang mereka sudah lakukan dalam penerapan system remunerasi berbasis kinerja pegawai yaitu : Mengadakan sosialisasi, dan disampaikan setiap kali di apel pagi maupun disampaikan pada saat kesempatankesempatan tertentu." (Wawancara 3 Oktober 2020)

Perlu adanya sosialisasi dari pihak terkait untuk memudahkan setiap pegawai akan merasa libih mengrti dan paham agar setiap pegawai bisa melakukan pekerjaan sesuai dengan kinerjanya dalam mendapatka remunerasi atau tambahan penghasilan.

\section{Rapat}

Rapat merupakan pertemuan atau berkumpulnya minimal dua orang atau lebih untuk memutuskan suatu tujuan.Rapat juga dapat dijadikan sebagai media untuk berkomunikasi antar manusia atau pimpinan kantor dengan staffnya atau karyawanya. Rapat juga dapat diartikan sebagai mediakomunikasikelompok yang bersifat tatap muka yang sering diselenggarakan atau dilakukan oleh banyak organisasi baik itu swasta ataupun pemerintah.

Upaya yang sering diberikan adalah dalam rapat agar setiap pegawai bisa mengetauhinya secara jelas, dan dapat melakukan 
setiap pekerjaannya sesuai dengan informasi yang sudah diberikan oleh pemerintah dalam menetapkan remunerasi atau tambahan penghasilan, sebagaimana di katakana oleh informan Bapak Yahya Syufan, S.sos beliau menjelaskan bahwa;

"Kembali berpulang ke Visi Misi bapak Bupati bahwa upaya pemerintah daerah untuk mensejatherakan pegawainya. Upaya untuk mengadakan sosialisasi, atau disampaikan setiap apel pagi, dan diberitahukan disetiap rapat." (Wawancara 3 Oktober 2020)

Upaya yang sering diberikan dalam rapat adalah agar setiap informasi dapat didengar secara langsung dari setiap masing-masing pegawai. Agar setiap pegawai dapat bekerja sesuai dengan apa yang diharapkan oleh pemerintah daerah dalam mendaptkan remunerasi atau tambahan penghasilan sesuai dengan kinerjanya.

\section{Apel Pagi}

Apel sering dilaksanakan pada pagi hari atau, apel pagi ini merupakan semacam upacara yang tujuannya untuk memberikan pengarahan sebelum memulai pekerjaan, apel juga digunakan untuk mengawasi siapa saja yang tidak hadir atau terlambat pada pagi hari.

Upaya juga yang dilakukan adalah diapel pagi, agar setiap pegawai dapat mengingat dalam melukakan setiap pekerjaan-pekerjaan sesuai dengan kinerjanya untuk menjalankan aktifitasnya sebelum bekerja di kantor sebagai bagian dari prosedur yang ada, lebih jelanya penulis mewawancarai informan atas nama Ibu Sanderina Abigael Su, A.md beliau mengatakan bahwa;

"Upaya yang dilakukan adalah Memberikan sosialisasi, memberikan pemberitahuan misalnya lewat rapat atau apel pagi, atau pengumuman lainya setiap ada pertemuan-pertemuan penting dan lain-lain." (Wawancara 3 Oktober 2020)

Selain itu ada unsur-unsur penilaian agar pegawai dapat menerima tunjangan kinerja yaitu berdasarkan absensi atau kehadiran kinerja, capaian kerja, dan disiplin pegawai. Tunjangan kinerja pegawai adalah tunjangan yang diberikan kepada pegawai berdasarkan capaian kinerja dari masing-masing pegawai. Untuk mengetahui hal tersebut penulis melakukan mewawancara dengan informan Ibu Fanny Minarni S.H.M.H. beliau memaparkan bahwa;

"Setiap pegawai berhak mendapatkan remunerasi sesuai dengan beban kerjannya. Jika seorang pegawai menerima remunerasi full apabila tugasnya dapat diselesaikan secara menyeluruh. Sedangkan pegawai yang pekerjaannya dilaksanakan tidak secara menyeluruh tentunya remunerasi yang didapatkanya akan fluktuatif, bisa turun bisa naik." (Wawancara 3 Oktober 2020) 
Dari hasil tersebut di atas menunjukan bahwa setiap pegawai berhak mendapatkan remuneras sesuai dengan beban kerjannya apabila menyelasaikan setiap pekerjaannya. Setiap pekerjaan yang dia kerjakan sesuai dengan target atau tepat pada waktunya maka dia berhak menerima remunerasi yang fuul atau sesuai. Apabila pegawai yang tidak melaksanakan pekerjaannya tidak sesuai dan tidak tepat pada target yang sudah ditentukan maka pegawai tersebut tidak berhak menerima remunerasi secara fuul atau menyeluruh.

\section{KESIMPULAN}

Berdasarkan pada hasil Penelitian ini tentang Sistem Remunerasi Berbasis Kinerja Pegawai Negeri Sipil di Kabupaten Sorong dapat disimpulkan bahwa sistem remunerasi berbasis kinerja Pegawai Negeri Sipil yang diterapkan di kantor Badan Kepegawian, Pendidikan dan pelatihan Kabupaten Sorong, sangat berpengaruh

\section{DAFTAR PUSTAKA}

Buku:

Muhammad Surya, Bunga Rampai Guru dan Pendidikan $2004 \quad$ Remunerasi finansial. Jakarta: Balai Pustaka.

Sugyono, 2009. Metode Penelitian Pendidikan Pendekatan Kuantitatif, Kualitatif dan $R \& D$. Bandung: Alfabeta. pada kinerja Pegawai sehingga Pegawai dapat bekerja lebih baik, lebih giat karena sebagian besar pegawai negeri sipil selama ini tidak bekerja secara efektif dan efisien, diharapkan dengan adanya sistem remunerasi dari pemerintah daerah maka pegawai dapat bekerja secara baik dan disiplin. Setiap tugas-tugas yang dikerjakan oleh seorang ASN dapat dimasukan dibuku jurnal harian masing-masing. setiap pegawai yang mendapatkan remunerasi atau tambahan penghasilan diharapkan dapat bekerja sesuai dengan kinerjanya masing-masing. sistem remunerasi dan kinerja itu berbeda dalam arti bahwa, sistem remunerasi atau tambahan penghasilan pegawai itu adalah soal kehadiran masing-masing pegawai, atau soal kedisiplinan, itu dihitung dalam setiap kinerja pegawai. Sedangkan kinerja adalah pekerjaan yang sudah ditentukan atau diberikan untuk setiap pegawai agar bisa dapat bekerja sesuai dengan kinerjanya masing-masing.

Sugiyono. (2014). Metode Penelitian Pendidikan Pendekatan Kuantitatif, Kualitatif, dan R\&D. Bandung: Alfabeta.

Peraturan Pemerintah Republik Indonesia Nomor 30 Tahun 2019 tentang Penilaian Kinerja Pegawai Negeri Sipil

Jurnal:

Purnomo, A. (2018). Pelaksanaan Kebijakan Komunikasi Organisasi 


\section{Noken Vol. 6 (No.1) Halaman: 49-62 2020}

Pemerintahan di Indonesia. Jurnal noken: Ilmu-Ilmu Sosial, 3(2), 1126.

Purnomo, A. (2018). Studi Kuantitatif: Biaya Transaksi Dalam Perspektif Manajemen Pemerintahan Di Indonesia. Jurnal Noken: Ilmu-Ilmu Sosial, 3(1), 21-30.

Listiawati, D. Y., Suaib, M. R., \& Purnomo, A. (2018). Restrukturisasi Birokrasi Dan Pengembangan Good Governance Kabupaten Sorong. Gradual, 7(1), 67-79.

Mambtisauw, D., Suaib, H., \& Purnomo, A. (2017). Efektivitas Dan Efisien Kinerja Organisasi Publik Di Distrik Kepulauan Ayau. Gradual, 6(2), 66-83. Syama, M., Amiruddin, A., \& Purnomo, A. (2019). Faktor Motivasi Dalam Kinerja Pegawai Pada Badan Kepegawaian Daerah Kota Sorong. Jurnal Faksi: Ilmu Sosial dan Ilmu Politik, 2(2), 12-20.

Yappen, M. M., Karsiman, K., \& Purnomo, A. (2019). Fungsi Dan Peranan Pemerintah Kabupaten Raja Ampat Dalam Proses Pembangunan Kesejahteraan Masyarakat. Jurnal Faksi: Ilmu Sosial dan Ilmu Politik, 2(2), 1-11.

Sulistiyani, S., Amiruddin, A., \& Purnomo,

A. (2019). Pengembangan Sumber Daya Manusia (Sdm) Dalam Kinerja Pegawai Distrik Aimas Kabupaten Sorong. Jurnal Faksi: Ilmu Sosial dan Ilmu Politik, 3(1), 32-40.

Thesia, F. B., Ali, M., \& Purnomo, A. (2019). Enterpreneurial Government Dalam Persepsi Pejabat Birokrasi Pemerintah Di Kabupaten Sorong Selatan. Jurnal Faksi: Ilmu Sosial dan Ilmu Politik, 2(4), 10-29.
Tuhumena, Y. S., Amiruddin, A., \& Purnomo, A. (2019). Kualitas Kerja Aparat Pemerintahan Dalam Pelaksanaan Pembangunan Di Distrik Aimas Kabupaten Sorong. Jurnal Faksi: Ilmu Sosial dan Ilmu Politik, 3(1), 50-61.

Salam, P. J. A., Suaib, M. R., \& Purnomo, A. (2019). Pengawasan kualitas prestasi kerja karyawan pt. Pln (persero) cabang sorong. Jurnal Faksi: Ilmu Sosial dan Ilmu Politik, 4(1), 44-50.

Mapadang, A., Suaib, M. R., \& Purnomo, A. (2019). Implementasi Sistem Administrasi Kependudukan Di Dinas Kependudukan Dan Pencatatan Sipil Kota Sorong. Jurnal Faksi: Ilmu Sosial dan Ilmu Politik, 3(4), 42-52.

\section{BIODATA SINGKAT}

Penulis bernama Arie Purnomo, lahir pada tanggal 17 Januari 1982 Sorong, pada pendidikan tingga penulis mengikuti studi pada Jurusan Ilmu Pemerintahan Universitas Ahmad Yani selanjutnya penulis melanjutkan studi S2 Pascasaejana Ilmu Perintahan Universitas Negeri Makassar, dan saat ini peneliti bekerja sebagai Dosen tetap Universitas Muhammadiyah Sorong Fakultas Ilmu Sosial dan Ilmu Politik Program Studi Ilmu Pemerintahan. 